\title{
PATBM Strategy for Reducing the Level of Violence Against Children (A Case Study in four Villages as Pilot Projects of PATBM in North Kalimantan, Indonesia)
}

\author{
Dr. Arif Jauhar Tontowi \\ Faculty of Economics, Kaltara University of Tanjung Selor, North Kalimantan, Indonesia
}

\begin{abstract}
PATBM strategy is the child protection movement being tested by the Indonesian government during 2016 in 136 villages nationwide. This strategy is conducted by moving the volunteers to those villages as the facilitators who work by bringing the mission of changing people's behavior in reducing the level of violence against children. This study was aimed to determine the effectiveness of the PATBM strategy, especially in the 4 villages as the pilot project in the province of North Kalimantan. Primary data collected was subsequently processed by using analytical tools SEM (Structural Equation Modeling). This research has resulted that PATBM strategy turned out the significant effect on the facilitators' competence. Afterwards, it influences behavioral change as well as reduces the level of violence against children significantly. Indirectly, PATBM strategy variable through intervenning variable, namely; facilitators' competence and behavioral change influences and significantly reduces the level of violence against children. The findings of this study can be used as the reference for the government in order to continue, replicate, and develop the program in other areas, so violence against children can be minimized Indonesia evenly.
\end{abstract}

Keywords: PATBM Strategy, facilitators' competence, behavioral change, violence against children.

\section{Introduction}

In Indonesia, PATBM is well-known as "Perlindungan Anak Terpadu Berbasis Masyarakat" or community-based integrated children protection. It was developed by the Ministry of Women and Children's empowerment of Republic of Indonesia (KPP-PA RI: Kementerian Pemberdayaan Perlindungan Anak Republik Indonesia) and conducted by moving the facilitators to change community's behavior about reducing of the violence level against children. This strategy moves the PATBM facilitators to extend from the national, provinces, districts/cities, and until villages level. 2016 year was the first year trials the strategy in 34 provinces, 68 districts and 136 villages. In particular, this study was aimed to determine the effectiveness of the PATBM strategy in the four villages as the pilot project located in the Province of North Kalimantan.

Results of the research on the violence against children in four provinces, namely: West Java, Jambi, East Nusa Tenggara and Central Java conducted by the KPP-PA RI in 2016, it had become the starting point of the movement strategies PATBM why those models designed and tested were. In that study, it was found that the trend of violence against children is constantly increasing. Actually, people have a lot of practice in child protection but it is still sporadic and conditional. In order to be more optimal in result, it is required a protection movement that is simultaneous and integrated. Moreover, it is conducted nationally in all regions of Indonesia and integrated by involving all elements of society both vertically and horizontally. In collaboration with a team of national facilitators formed by the Center for Women Studies (PSW: Pusat Studi Wanita) at the universities in the four provinces, KPP-PA RI succeeded in designing a strategy model of the community-based integrated children protection $(P A T B M)$ which was expected if the implementation would be able to reduce the level of violence against children.

Gambit (2016) as a PATBM national facilitator, in his briefing session on monitoring and evaluation of the PSW 16 participants from all over Indonesia at the Horison Hotel Bekasi in 2016 emphasized that the success of the PATBM movement strategy will be measured from feasibility and acceptability. It means that feasibility is the real manifestation from the movement of PATBM mission in the society, while acceptability is how strong the level of public acceptance against the presence of PATBM in their environment. Thus, the feasibility and acceptability are divided into two indicators which to measure the success of the PATBM strategy movement. 2016 is the year of the beginning of the trial. Simultaneously, throughout Indonesia selected locations pilot project to determine the distribution of the location of the two villages in each district and two districts in each province, there are 136 villages were selected as the location of the pilot project implementation PATBM strategy movement. In North Kalimantan, it was determined Jelarai Selor Village and Gunung Sari Village located in Bulungan District and NunukanTengah Village and Tanjung Harapan Village located in Nunukan District as the pilot projects of PATBM location. 
In those four villages as the pilot project, it had been appointed 10 facilitators for each village, so the total number of facilitator was 40 facilitators. Those facilitators had followed training of trainers (TOT). The training was trained by 2 facilitators from Bulungan District and 2 facilitators from Nunukan District. In addition, the training was also trained by 3 facilitators from North Kalimantan Province and 1 facilitator from the national level. This training was aimed to increase the facilitator's competences in order to be able to implement PATBM mission in society successfully.

Theoretically, Spencer and Spencer (1999) argues that an individual's competence (facilitator) includes five indicators, namely; skills, knowledge, self-concept, motives and traits. Being given the briefing material PATBM during the TOT, those five indicators of competence in each individual of the facilitators will be increased, so they are able to success in the mission PATBM movement village's respectively through actions, such as interventions. Therefore, the ability of the facilitator in carrying out his or her role in PATBM movement can be seen from those five indicators. Within the framework of PATBM (Pedoman PATBM, 2016), the intervention of the facilitators in PATBM movement is to create behavioral change in society and expected to have an impact on the level of violence in children. Behaviors that cause or trigger violence against children in the community are expected to change with the movement the PATBM strategy. The behavior changes include, namely; a change in norms, ability to avoid violent, and response to violence. If during this time are the norms, the ability to avoid violence and how to respond to violence improper/no good, expected after the intervention of the facilitator will be amended to be more appropriate or better. All three forms of this behavior change the indicators on behavior change interventions targeted results. Thus the three indicators is a measure of success in behavioral change variable.

With the onset of behavioral changes in these communities, it is expected that eventually PATBM movement strategies can effectively reduce the occurrence of child abuse. The intended forms of violence include physical, psychological, sexual, neglect and bullying. All four forms of violence have become dimensions at once indicator in measuring the end result of this PATBM movement strategy. If these forms of violence are perceived by the public decreased after intervention by the facilitators, then PATBM considered successful. If otherwise, it needs to be re-evaluated and repaired parts of the system PATBM movement strategies.

\section{Objectives}

1. To find out the impact of PATBM strategy on facilitators' competence.

2. To find out the impact of facilitators'competence on behavioral change.

3. To find out the impact of behavioral change on reduction of violence against children.

4. To find out the indirect impact of PATBM strategy through an intervening variable, namely: facilitators' competence and behavioral change in order to reduce violence against children.

\section{Literature Review \\ 3.1. PATBM (Perlindungan Anak Terpadu Berbasis Masyarakat /Community-Based Integrated Children Protection)}

PATBM is a movement strategy from the network or group of people at the community level that works coordinately in order to achieve the purpose of children protection. PATBM is a community initiated by people in order to undertake the prevention efforts by building public awareness to change knowledge, attitudes, and behaviors that provide protection to children. The movement can be managed by using and developing the institutional structures function that already exists or if it is needed by establishing a new institutional structure (Pedoman PATBM, 2016).

The emergence of the PATBM movement strategies is motivated by several concerns, especially the fact that shows violences against children are likely to continue to rise uncontrollably. Indonesiana.tempo.co (2016) explains that in 2015,KPPPA-RI conducted a research in four provinces, namely: West Java, Central Java, East Nusa Tenggara, and Bengkulu. It was aimed to identify best-practice protocols practices undertaken child protection society, the obstacles encountered, and the potential for development. The results obtained from the information is the child protection community has done a lot, ranging from disseminating children's rights in the form of art, dialogue, media publishing information to accompany when a child victim. Although it has been a lot of activity, it demands a protection for children and prevention remains necessary.

\subsection{Facilitators' Competence}

Competence is the facilitator competencies possessed by the PATBM facilitators. Competence can be defined as a basic fundamental knowledge, ability, experience, and requirements that are necessary to carry out the work successfully (Mudjiman, 2007). While Mathis and Jackson (2001) define that competence are the basic characteristics that may be associated with an increased performance of individuals or teams, consisting of knowledge, skills and capacity. Characteristics of this competence are developed by Spencer and Spencer 
(1993) into five types, namely: knowledge, skills, self concept, motive, and traits. The existence of the five characteristics found in the individual compentence is so easily observed, and there are hidden within the personality.Competencies of knowledge and skills visible and easily recognizable on the surface as a characteristic of the individual. Competencies self concept, motive and traits are not directly visible and located at the central point of one's personality. The skills and knowledge more easily developed through training programs. While the self concept, motive and traits are relatively more difficult to develop and require time and special methods (Tontowi, 2016).

\subsection{Behavioral Change}

Behavior applying to the individual or organism does not happen automatically, but it is as a result of the stimulus received by the organism in question both the external and internal stimulus (Walgito, 2003). Based on this opinion, it can be concluded that the purpose of creating behavioral change in individuals or groups of people can be done through a specific process, for example by learning or training as a form of stimulus to get them to change behavior.

In the context of PATBM movement strategy, the ongoing process in the implementation of this movement is seen as a process of intervention or stimulus to community members so that they could make behavioral changes that result in a decrease of violence against children. Within the framework of PATBM (Pedoman PATBM, 2016), the implementation of this motion is expected to influence behavior change in the community that there are three changes its shape, namely; 1 . Strengthening and change in norms, 2. Ability to avoid violence, and 3. Response to the violence.

\subsection{Violence Against Children}

The level of violence against children in Indonesia needs an attention from all sides seriously, because the numbers continue to rise with a relatively is large. The data from KPAI (Komisi Perlindungan Anak Indoneisa or Indonesian child protection commission) in 2014 showed that cases of violence from 2011 to 2014 increased from 2,178 cases to 5,066 cases.

The forms of violence that occurs in children five kinds (Maharani, et al, 2016), namely; physical violence, sexual violence, psychological violence, neglect and bullying. Physical violence is violence easily known and seen directly on the victim's body. Based on the Domestic Violence Law number 23 year 2004, physical violence, among others beaten, kicked, slapped, bruised, tufted, pinched, pitted, dried in the sun, and so on. Sexual violence is any act of forcing sexual intercourse, by way of unnatural and / or disliked, forced relationships with other people for commercial purposes and / or a particular purpose. Psychological violence is an act that can result in fear, loss of confidence, loss of ability to act, a sense of helplessness, and / or serious psychic suffering for someone.Abandonment is the act of an adult or a parent or guardian (who is legally responsible for the welfare of the children during the care giving) that do not give or provide the basic needs of children, despite the fact that resources available to meet those needs. Bullying is the pressure and intimidation is continuously being done to hurt someone both physically and emotionally.

\section{Methodology}

This study employed quantitative approach. The data of this study were collected from survey methods, namely: interview and questionnaire. The research instrument used was a set of questions (in questionnaire) and distributed to the respondents. Samples are 152 respondents in 4 villages PATBM pilot project location. The sampling technique used was quota-purposive-accidental sampling. Each village of the pilot project location obtained the same portion, namely 38 respondents, so the sample size is 152 respondents overall. Respondents were selected that is deemed to understand about the research variables and community members who have been following the activities undertaken by the villages PATBM facilitator. Questionnaires were administered to respondents these criteria to be fulfilled requirements specified number of samples. The kind of analysis employed in the study was the inferential statistical analysis. The analysis of data from the respondents used the Structural Equation Modelling (SEM) with the assist of AMOS 20 and SPSS 20 programs.Formulating the structural equation model in the study referred to the steps once developed by Hair (2006) which comprise: (1) Theoretical-based Model Development, (2) Path Diagram Development, (3) Evaluation on Goodness of Fit Criteria, (4) Assumption Assessment of the SEM, and (5) Structural Model Testing: Testing the Research Hypothesis.

\subsection{Research Instrument Testing}

\section{Findings And Discussion}

Table 1 shows the result of the research instrument testing (in terms of validity and reliability). 
Table 1.Validity and Reliability Testing

\begin{tabular}{|c|c|c|c|c|c|c|c|}
\hline \multicolumn{2}{|c|}{ PATBM Strategy $(\mathrm{X})$} & \multicolumn{2}{|c|}{ Facilitators Competnce(Y1) } & \multicolumn{2}{|c|}{ Behavioral Change (Y2) } & \multicolumn{2}{|c|}{$\begin{array}{l}\text { Violence Against Children } \\
\text { (Y3) }\end{array}$} \\
\hline Indicator & $\begin{array}{l}\text { Correl } \\
\text { ation }\end{array}$ & Indicator & $\begin{array}{l}\text { Correla } \\
\text { tion }\end{array}$ & Indicator & $\begin{array}{l}\text { Correla } \\
\text { tion }\end{array}$ & Indicator & $\begin{array}{l}\text { Correla } \\
\text { tion }\end{array}$ \\
\hline Feasibility (X1) & 0.523 & Knowledge (Y1.1) & 0.648 & $\begin{array}{l}\text { Change in } \\
\text { Norm (Y2.1)) }\end{array}$ & 0.539 & $\begin{array}{l}\text { Physical violence } \\
\text { (Y3.1) }\end{array}$ & 0.830 \\
\hline Acceptability (X2) & 0.523 & Skill (Y1.2) & 0.631 & $\begin{array}{l}\text { Ability to avoid } \\
\text { violence(Y2.2) }\end{array}$ & 0.740 & $\begin{array}{l}\text { Psychological } \\
\text { violence (Y3.2) }\end{array}$ & 0.797 \\
\hline- & - & Concept & 0.704 & $\begin{array}{l}\text { Response to the } \\
\text { violence(Y2.3) }\end{array}$ & 0.782 & $\begin{array}{l}\text { Sexual violence } \\
\text { (Y3.3) }\end{array}$ & 0.766 \\
\hline - & - & Motive (Y1.4) & 0.550 & - & - & Neglect (Y3.4) & 0.753 \\
\hline- & - & Traits (Y1.5) & 0.478 & - & - & Bullying (Y3.5) & 0.803 \\
\hline \multicolumn{2}{|c|}{ Alpha Cronbach $=0.688$} & \multicolumn{2}{|c|}{ Alpha Cronbach $=0.811$} & \multicolumn{2}{|c|}{ Alpha Cronbach $=0.824$} & \multicolumn{2}{|c|}{ Alpha Cronbach $=0.916$} \\
\hline
\end{tabular}

Source: Data analysis, 2016

\subsection{The SEM Analysis}

5.2.1 Normality

The assumption of multivariate normality was tested by using AMOS 20 computer software. The result shows that the value of critical ratio was -0.943 with critical value $Z_{\text {counted }}$ for $\alpha 5 \%$ was 1.96 . Since the CR absolute value of multivariate showed that $0.943<1.96$, the assumption of multivariate normality was satisfied.

\subsubsection{Outlier}

When the Md of the observation spot $>107.2579$, it was said as outlier. On the contrary, when the Md of the observation spot $<107.2579$, it cannot be said as outlier. The table of Mahalanobis distance shows that the farthes observation spot was the $53^{\text {rd }}$ respondent with Md value $=27.410$. If this was to be compared with the value of $\chi_{66}^{2}=107.2579$, then the value of $\mathrm{Md}$ in the $53^{\text {rd }}$ spot $<107.2579$, and, thus, all the observation spots were not outlier.

\subsubsection{Linearity}

Table 2. Result of Testing on Linearity Assumption

\begin{tabular}{|l|l|l|l|}
\hline \multicolumn{2}{|l|}{ Relationship between Variables } & Result & Signification \\
\hline PATBM Strategy (X) & Facilitators Competnce (Y1) & Sig for all models $<0.05$ & Linier \\
\hline Facilitators' Competence (Y1) & Behavioral Change (Y2) & Sig for all models $<0.05$ & Linier \\
\hline Behavioral Change (Y2) & Violence Against Children (Y3) & Sig for all models $<0.05$ & Linier \\
\hline
\end{tabular}

Source: Data analysis, 2016

\subsection{Goodness of Fit Overall Model}

Table 3. Result of Testing on Goodness of Fit Overall Model

\subsection{Measurement Model (CFA)}

\begin{tabular}{|l|l|l|l|}
\hline Criteria & Cut-of Value & Result & Signification \\
\hline Khi Quadratic & Small & 77.779 & Good \\
\hline p-value & $\geq 0.05$ & 0.641 & \\
\hline CMIN/DF & $\leq 2.00$ & 0.937 & Good \\
\hline GFI & $\geq 0.90$ & 0.920 & Good \\
\hline AGFI & $\geq 0.90$ & 0.884 & Poor \\
\hline TLI & $\geq 0.95$ & 1.019 & Good \\
\hline CFI & $\geq 0.95$ & 1.000 & Good \\
\hline RMSEA & $\leq 0.08$ & 0.000 & Good \\
\hline
\end{tabular}

Source: Data analysis, 2016

Table 4. Result of Testing on Measurement Model

\begin{tabular}{|l|l|l|l|}
\hline PATBMStrategy Variable & Standardized & P-value & Meaning \\
\hline Indicator & $\mathbf{0 . 7 8}$ & 0.002 & Significant \\
\hline X.1 = Feasibility & 0.67 & 0.000 & Significant \\
\hline X 2 = Acceptability & \multicolumn{3}{|l|}{} \\
\hline Facilitators Competence Variable (Y1) & Standardized & P-value & Meaning \\
\hline Indicator & 0.79 & 0.001 & Significant \\
\hline Y1.1 = Knowledge & 0.75 & 0.001 & Significant \\
\hline Y1.2 = Skill & $\mathbf{0 . 8 6}$ & 0.000 & Significant \\
\hline Y1.3 = Self Concept & 0.52 & 0.001 & Significant \\
\hline Y1.4 = Motive & 0.44 & & \\
\hline Y1.5 = Traits & \multicolumn{3}{|l}{} \\
\hline BehavioralChange Variable (Y2) & Standardized & P-value & Meaning \\
\hline Indicator & 0.59 & 0.001 & Significant \\
\hline Y2.1 = Change in Norms
\end{tabular}




\begin{tabular}{|l|l|l|l|}
\hline Y2.2 = Ability to avoid violence & 0.87 & 0.001 & Significant \\
\hline Y2.3 = Response to the violence & $\mathbf{0 . 9 1}$ & 0.001 & Significant \\
\hline Violence Against Children (Y3) & Standardized & P-value & Meaning \\
\hline Indicator & $\mathbf{0 . 8 7}$ & 0.000 & Significant \\
\hline Y3.1 = Physical violence & 0.85 & 0.001 & Significant \\
\hline Y3.2 = Psychological violence & 0.80 & 0.001 & Significant \\
\hline Y3.3 = Sexual violence & 0.79 & 0.001 & Significant \\
\hline Y3.4 = Neglect & 0.85 & 0.001 & Significant \\
\hline Y3.5 = Bullying
\end{tabular}

Source: Primary data analysis, 2016

\subsection{Result of Hipothesis Testing}

Table 5 and 6 show the result of the hypothesis testing on the existence of direct and indirect impact of CSR strategy.

Table 5. SEM Result of Structural Model: Direct Impact

\begin{tabular}{|l|l|l|l|}
\hline Relationship between Variables & Coefisien & P-value & Meaning \\
\hline PATBM Strategy $(\mathrm{X}) \rightarrow$ Facilitators Competence $(\mathrm{Y} 1)$ & 1.05 & $* * *$ & Significant \\
\hline Facilitators Competence $(\mathrm{Y} 1) \rightarrow$ Behavioral Change $(\mathrm{Y} 2)$ & 0.34 & $* * *$ & Significant \\
\hline Behavioral Change $(\mathrm{Y} 2) \rightarrow$ Violence Against Children (Y3) & 0.33 & $* * *$ & Significant \\
\hline
\end{tabular}

Source: Primary data analysis, 2016

Legend : Marker * states significancy with margin of error 5\%

Table 6. SEM Result of Structural Model: Indirect Impact

\begin{tabular}{|l|l|l|l|l|l|}
\hline Indirect Impact & $\begin{array}{l}\text { Direct Impact } \\
\text { Coeficient }\end{array}$ & $\begin{array}{l}\text { Direct Impact } \\
\text { Coeficient }\end{array}$ & $\begin{array}{l}\text { Direct Impact } \\
\text { Coeficient }\end{array}$ & $\begin{array}{l}\text { Indirect Impact } \\
\text { Coeficient }\end{array}$ & Meaning \\
\hline $\mathrm{X} \rightarrow \mathrm{Y} 1 \rightarrow \mathrm{Y} 2 \rightarrow \mathrm{Y} 3$ & $\mathrm{X} \rightarrow \mathrm{Y} 1=1.05$ & $\mathrm{Y} 1 \rightarrow \mathrm{Y} 2=0.34$ & $\mathrm{Y} 2 \rightarrow \mathrm{Y} 3=0.33$ & 0.12 & Significant \\
\hline
\end{tabular}

Source: Primary data analysis, 2016

Legend: Marker * states significancy with margin or error $5 \%$

\section{Discussion}

\subsubsection{The Facilitators' Competence Increases in Line with the Increase of PATBM Strategy}

From the results of the analyses, the coefficient correlation of PATBM strategy and facilitators competency is 1.05 with $\mathrm{p}$-value of $* * *(\ldots<0.001)$. Since the $\mathrm{p}$-value is $<0.05$, it indicates that PATBM Strategy has a significant correlation with facilitators' competency. In addition, the positive mark on the coefficient indicated a one-way direction. Thus, it means that the higher the value of PATBM strategy, the higher the fasilitator' competence will be.

Based on the SEM analyses, PATBM strategy is measured through two indicators, namely; feasibility and acceptability, in which the first is the most crucial indicator in the measurement of PATBM strategy within the present study. In other words, the worth of PATBM strategy mostly lies in the feasibility aspect of PATBM programs.Facilitators'competency is measured through fiveindicators in SEM, namely; knowledge, skill, self concept, motive and traits, in which the third becomes the most crucial indicator in the measurement of facilitators' competence. Thus, the worth of facilitators'competncemostly lies in the self conceptaspect.The results of the analyses indicate that the better implementation of PATBM strategy has brought such a positive effect on facilitators' competence. This means that improvement upon PATBM strategy can mainly be seen through improvement on its feasibility indicators, will create such higher facilitators competence, and can mainly be seen through the level of self concept.

\subsubsection{The Behavioral Change Increases in Line with the Increase of Facilitators Competence}

From the results of the analyses, the coefficient correlation of facilitators'competence andbehavioral change is 0.34 with p-value of $* * *(\ldots<0.001)$. Since the $p$-value is $<0.05$, it indicates that facilitators'competence has a significant correlation with behavioral change. In addition, the positive mark on the coefficient indicated a one-way direction. Thus, it means that the higher the value of facilitators' competence, the higher the behavioral change will be.Based on the SEM analyses, facilitators' competence is measured through five indicators, namely; knowledge, skill, self concept, motive and traits, in which the third is the most crucial indicator in the measurement of facilitators' competence within the present study. In other words, the worth of facilitators' competence mostly lies in the self conceptaspect.

Behavioral change is measured through three indicators in SEM, namely; Norms change, ability to avoid violence, and response to the violence, in which the third becomes the most crucial indicator in the measurement of behavioral change. Thus, the worth of behavioral change is defined mostly by masyarakat identification - meaning that the worth of behavioral change can be seen through public response to violence. The results of the analyses indicate that the better implementation of facilitators' competence has brought such a 
positive effect on behavioral change. This means that improvement upon facilitators' competencecan mainly be seen on its self concept aspect, will create such higher behavioral change, and can mainly be seen through the level of public response to violence.

\subsubsection{The Violence against Children Decreases in Line with the Increase of Behavioral Change}

From the results of the analyses, the coefficient correlation of behavioral change and violence against childrenis 0.33 with $\mathrm{p}$-value of $* * *(\ldots<0.001)$. Since the $\mathrm{p}$-value is $<0.05$, it indicates that behavioral change has a significant correlation with violence against children. In addition, the positive mark on the coefficient indicated a one-way direction. Thus, it means that the higher the value of behavioral change, the higher the decreases violence against childrenwill be. Based on the SEM analyses, behavioral change is measured through three indicators in SEM, namely: norm change, ability to avoid violence, and response to the violence, in which the third becomes the most crucial indicator in the measurement of behavioral change. Thus, the worth of behavioral change is defined mostly by masyarakat identification - meaning that the worth of behavioral change can be seen through of public response to violence

The decline of violence against childrenis measured through fiveindicators in SEM, namely; physics violence, psychological violence, sexual violence, neglect and bullying - in which the five becomes the most important indicatorin order to measure violence against children. This means that the value of violence against childrenshould mostly be seen through kekerasanfisikaspect. The results of the analyses show that behavioral change and reduction of the violence against childrenare positively correlated; which means that the improvement over behavioral change can mainly be seen through response to the violence and also will improve decline of violence against children.

\subsection{Research Implications}

Based on the findings, the present study is expected to have some theoretical and practical implications, as follows:

1. Theoretically, the concepts and models developed in this study is a new finding because it does not exist before. PATBM strategy is a new strategy likes a child protection system implemented in Indonesia effectively. It has a contribution to the scientific development related to the implementation of a strategy in the development of human resource competency (facilitator's competence) which aims to change people's behavior and reduce the level of violence against children in Indonesia.

2. In terms of practical results of this study, it has proven an effective model in protecting children from violence. Thus, this model has greatly helped the government and people, especially four villages as pilot project in the province of North Kalimantanin order to protect children from violence.

\section{Conclusion}

The conclusions of the present study are as follows:

1. PATBM Strategy significant effect on the facilitators'competence.

2. Facilitators' competence significant effect on behavioral change.

3. Behavioral change significant effect on decreasing the level of violence against children.

4. Indirectly, PATBM strategy variable through two variables intervening facilitators' competence and behavioral change significant effect on decreasing the level of violence against children.

5. Indicators $P A T B M$ strategy implementation has the highest weighting is feasibility, which is how the public can see or watch PATBM activities take place. Indicators of facilitators'competence have the highest weighting is self-concept, namely:the ability of the facilitators in showing who they are and how to put themselves as well as how to carry out the duties, functions and role as a facilitator in the community. Indicators of behavioral change that has the highest weighting is the public response to violence against children, is to save the victims, accompany, report to the competent authority to deal with violence as well as indicators of decline in the level of violence against children that have the highest weighting is physical violence, the various forms of violence that lead to illness, injury or physical injury.

\section{Suggestions}

Based on the findings in this study, it is recommended thatit should be developed on a massive scale $P A T B M$ strategy to several other areas as one of the effective instruments in order to reduce the level of violence against children.

\section{References}

[1]. Gambit, 2016, Hand Out Materi Monitoring Dan Evaluasi PATBM. Disampaikan dalam acara penguatan fasilitator PATBM, 18-20 Agustus 2016, Hotel Horison Bekasi.

[2]. Spencer, M Lyle, Jr \& Signe M. Spancer, 1993, Competency at work “Models for Superior Performance”, John Wiley \& Sons Inc, New York. 
[3]. Anonim, 2016, Pedoman Perlindungan Anak Terpadu Berbasis Masyarakat (PATBM), edisi 1 Pelaksanaan Terbatas, Kementerian Pemberdayaan Perempuan dan Perlindungan Anak Republik Indoneisa (KPP-PA RI), Jakarta.

[4]. Tontowi Jauhar Arif, 2016, Buku Ajar Manajemen Operasional I, PustakaRadja, Surabaya.

[5]. http://indonesiana.tempo.co/read/80161/2016/06/30/kekekapri.1/perlindungan-anak-terpadu-berbasis - masyarakat - patbm, diakses tgl 29 Juli 2016.

[6]. Walgito, Bimo, 2003. Pengantar Psikologi Umum. Penerbit Andi, Yogyakarta.

[7]. Mudjiman Haris, 2007, Manajemen Pelatihan Berbasis Belajar Mandiri, Pustaka Pelajar, Yogjakarta.

[8]. Mathis, R. L., dan J. H. Jackson, 2001, Manajemen Sumber daya Manusia, buku 1, Terjemahan, Salemba Empat, Jakarta.

[9]. Maharani Dewi Farida, dkk, 2016, Anak Adalah Anugerah: Stop Kekerasan terhadap Anak, Kementerian Komunikasi dan Informasi Republik Indonesia dan Kementerian Pemberdayaan Perempuan dan Perlindungan Anak Republik Indonesia, Jakarta

[10]. Hair, Jr., J.F., R.E Anderson, R.L. Tatham and W.C. Black. 2006. Multivariate Data Analysis with Reading. Macmillan Pub. Company. New York. 